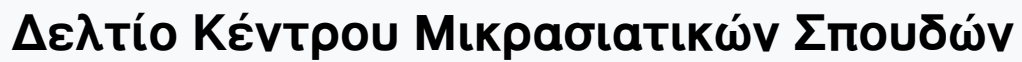

Tó 13 (1999)

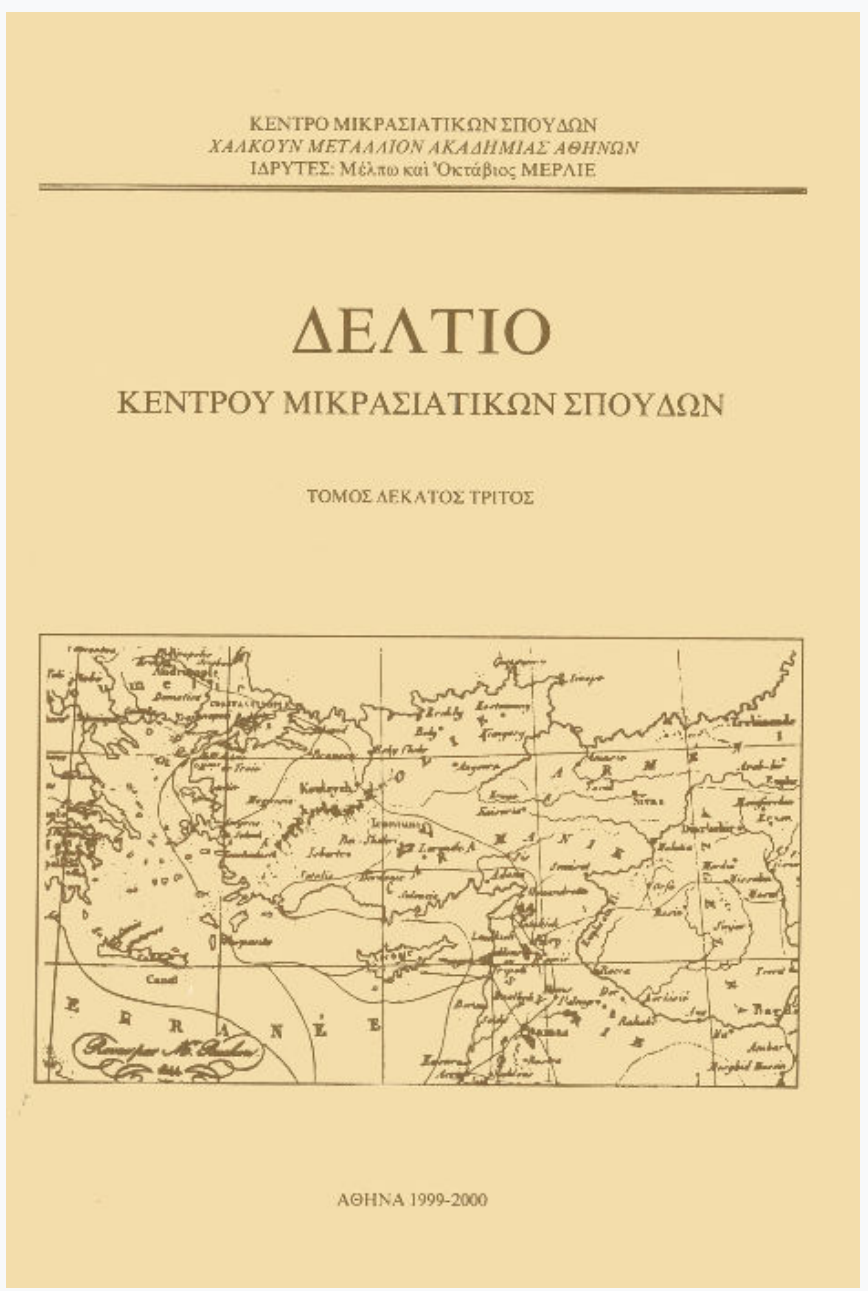

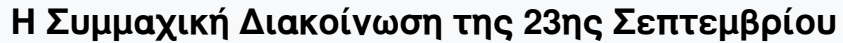

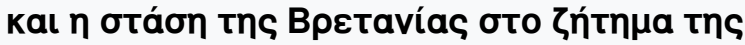 avatoגıкńs Өpákns}

Thanassis Bravos

doi: $\underline{10.12681 / \text { deltiokms.146 }}$

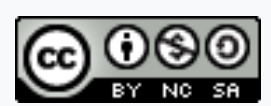

Aঠ¿ıı Xpńбnৎ Creative Commons Attribution-NonCommercial-ShareAlike 4.0.

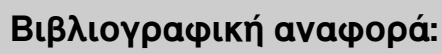

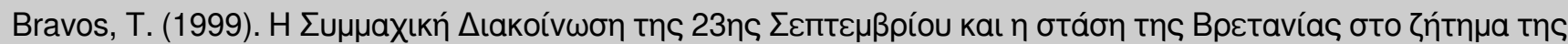

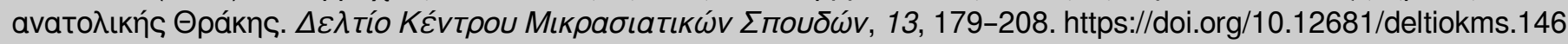




\section{THE ALLIED NOTE OF 23rd SEPTEMBER AND GREAT BRITAIN'S RETREAT ON THE QUESTION OF EASTERN THRACE}

On 23rd September 1922 the dramatic effort on the part of the Greek nation to achieve its national integration came to an end. After three days of stormy dispute and intense recrimination the Entente Powers decided to enter into negotiations with Mustapha Kemal (the Turkish Nationalist leader) with a view to producing an armistice, conceding to him, however, in advance, Eastern Thrace', thus making the Turks once again absolute sovereign in Constantinople and the Straits. The news that Great Britain had yielded to all the Franco-Italian pressures, which concurred with Kemal's demands, caused an extreme response. The fact, in particular that the above-mentioned concession took place just after the British Prime Minister's statement that the London Government would not agree to commit themselves as far as the Straits and Eastern Thrace ${ }^{2}$ were

1. Foreign Office (=F.O.) 371/7893, E $9783 / 27 / 44$, Hardinge (British Ambassador) to Curzon (Secretary of State for Foreign Affairs), Paris, 23 September 1922; M. L. Smith, Ionian Vision: Greece in Asia Minor, 1918-1922, London 1973, p. 317. Nevertheless, before promising anything about Eastern Thrace, the British wanted at first to secure their interests, viz. to be assured about the neutral zones. D. Walder, The Chanak Affair, London 1969, p. 308.

2. Archives of the Greek Ministry of Foreign Affairs (= A.Y.E.), 1922, A/5/VI ${ }_{(27)}, 3136$, Ragavis (Greek Ambassador) to Foreign Ministry, London, 6 September 1922. 
concerned, gave rise to a great deal of speculation about the viability of Lloyd George's Government.

This surprise, which brought about Britain's change in attitude, could not be considered unjustifiable: the well-known view of the British Prime Minister of the Greeks and the importance which he attributed to the fulfilment of their national aspirations had established London as the most ardent supporter of the enforcement of Sevres' Treaty terms upon the defeated Turkey. Furthermore, the importance of the Straits for the maintenance of the Empire's superiority over the Mediterranean Sea, thus safeguarding the lines of communication with India, drove Great Britain to support the Greek cause.

Not unreasonably, Lloyd George believed that a powerful Greek state could connect, like a channel, the heart of the Empire to its African colonies and those in the Near and Far East and that it would become one of the guarantees by which the main communication network of the Empire could be preserved ${ }^{3}$. He believed, furthermore, that maintaining such a valuable ally demanded, on Britain's part, continuous friendship and uninterrupted assistance. He regarded the Greek people as the people of the future in the Eastern Mediterranean, since they were productive and full of dynamism and, in addition, they possessed all the most important islands of that sea, which could be potential (British) submarine bases of the future ${ }^{4}$.

On the other hand, the Straits, whether closed or open, could be used to keep the Russian Black Sea Fleet out of the Mediterranean Sea. This line of action -pursued throughout the 19th century- demonstrated that the problem of the Straits was rather an Anglo-Russian problem than an Anglo-Turkish one. For that matter, Marshal Foch made it clear in a memorandum of his that the freedom of the Straits was "one of the principal fruits of the War" and for that reason he objected to the Turks being given control of the Straits.

Given the afore-mentioned, Great Britain's decision not to allow the Turks to cross Europe and land on Eastern Thrace, an act which would jeopardise her

3. A.Y.E., 1922, A/5/VI ${ }_{(9)}, 2129$, Ragavis to Foreign Ministry, London, 18 June 1922; For that reason he favoured the imperativeness of the landing of Greek troops at Smyrna. As Venizelos informed Em. Repoulis (acting Prime Minister) "[...] The British Prime Minister is determined to impose the Peace Treaty on Turkey in collaboration with Greece [...]", A.Y.E., 1920, A/4 , 2948 , Venizelos to acting Prime Minister, 15 June 1920.

4. W. S. Churchill, The World Crisis, vol. V: The Aftermath, London 1929, p. 391.

5. Documents on British Foreign Policy (= D.B.F.P.), 1919-1939, First Series, XVIII (19221923), London 1970, Appendix I, p. 980. 
position in the Gallipoli peninsula, could be considered not only predictable but imperative; their move into Europe would cause the collapse of British post-war defence structure, since the control of the Straits -and consequently that of the Eastern Mediterranean and Middle East base- had been the principal objective of the British Government. For that reason the latter, on 7 September decided that, whatever the events in Anatolia, Thrace would be Greek and Gallipoli Allied ${ }^{6}$, while on 11 September, that Government made it clear it was quite determined not to abandon the Gallipoli peninsula but, in addition, to keep Constantinople at all costs, even in the event of the Italians and the French refusing to make a common front with them? . However, as the Allied positions on the European side of the Straits would be in danger, if the Turks possessed the Asiatic side, it was decided the latter should be kept away from the territory opposite both Constantinople and the Gallipoli peninsula because, as Harington explained:

[...] with Nationalists' guns, aircraft and rifles on the Asiatic side, we could not remain in Constantinople, neither could ships proceed through the Bosphorus or remain in anchorage ${ }^{8}$.

At that moment, the Greek army was selected once again -although provisionally - to play an essential role: it was to be concentrated and reorganized in Eastern Thrace, so as to assist the Allied forces decisively in preventing the Turks from invading Europe'. That suggestion on the part of the British had been imposed by the circumstances ${ }^{10}$, since it was understood that the Greeks, by boosting their

6. B. C. Busch, Mudros to Lausanne: Britain's Frontier in West Asia, 1918-1923, New York 1976, p. 342.

7. D.B.F.P., XVIII, no. 21; After the statement of 16 September the War Office explained to Harington (Commander of the British troops at the Straits), thus: "The foundation of all our policy is the Gallipoli peninsula and the freedom of the Straits. For this reason it is of the highest importance that Chanak should be held effectively. Quite apart from its military importance it has now become a point of immense moral singificance to the prestige of the Empire [...] A blow at Chanak is a blow at Britain [...]". D.B.F.P., XVIII, no. 43; See also M. Kent., "British Policy, International Diplomacy and the Turkish Revolution", International Journal of Turkish Studies, vol. $3_{(2)}$, (Winter) 1985-1986, p. 43; M. L. Smith, op.cit., p. 316.

8. D.B.F.P., XVIII, no. 23.

9. A.Y.E., 1922, A/5/VI ${ }_{(4)}, 2947$, Ragavis to Foreign Ministry, London, 6 September 1922; D.B.F.P., XVIII, no. 33 .

10. The proposal to retain Eastern Thrace the Greeks was not a new one; on the contrary was the most agreeable to Foreign Office on condition that Greece should renounce her claims upon Smyrna. 
morale as long as they acted with the Allies, would defend not only their territory but the Entente's wounded prestige as well. Besides, according to Churchill:

[...] the re-entry of the Turks into Europe as conquerors [...] after all that had happened in the War, would signal the most humiliation of the Allies".

Undoubtedly, the above-mentioned plan fulfilled all the preconditions of success, taking into account the fact that Kemal -despite all his unreasonable demands- had not the power to take anything more than Asia Minor ${ }^{12}$. Without command of the sea he would not be able to transfer his troops to Eastern Thrace through the sea of Marmara, whilst it would be impossible to do so through the Boshporus, since Constantinople stood under Allied occupation. Furthermore, the Greek army would not be, in this case, far away from its base and supply lines -as had happened in Asia Minor- but inside its own country. Moreover, the Nationalists' leader himself was convinced that crossing to Europe was impossible, because his army was worn out and very far from its base ${ }^{13}$.

In spite of the aforesaid, which made obvious the fact that the accomplishment of London's objectives had been inevitably connected with the success of the Greek army - since "the hurried evacuation of Asia Minor by the Greek army, would endanger British positions in Constantinople and Iraq, as well as at the Straits" ${ }^{\prime \prime}$, the British Government conceded to the Turkish demands. Great Britain accepted the concession of Eastern Thrace to the Turks without a fight, in contrast to the previous decisions about the unacceptability of the Greek army's withdrawal beyond Maritza river and the really interesting view about it: as the cheapest weapon, the Greek army could be the most effective advantage in the event that the Kemalists threatened Constantinople and landed on Gallipoli peninsula ${ }^{15}$.

Such a decision, of course, neither could nor should be considered as a result of only one factor or an outcome of hasty deliberation. The reasons are several: (a) the failure of the Greek army to impose the terms of the Treaty of Sevres upon

D. Lloyd George, The Truth about the Peace Treaties, vol. II, London 1938, pp. 1233-1234.

11. Churchill, op. cit. p. 419.

12. D.B.F.P., XVIII, no. 10.

13. This Kemal's view is quoted in S. Araloff's memoirs (Soviet Ambassador in Ankara from

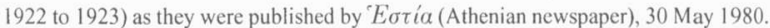

14. F.O. 371/7885, E $8873 / 27 / 44$, Rumbold (High Commissioner) to Foreign Office, Constantinople, 4 September 1922

15: F.O. 371/7886, E 9089/27/44, Foreign Office to Rumbold, 10 September 1922; D.B.F.P., XVIII, no. 34 . 
the Nationalists, (b) the resurgence of Turkish power and the revival of its threat in combination with its relations with the communist regime in Soviet Russia, as well as the latter's policy towards the Kemalists, (c) the continually close relations between France and Italy on the one hand and the Kemalists on the other -which finally caused the total breakdown of the supposed Entente's common front, and the desertion of these two Powers-, (d) the hostile feelings with which not only British public opinion but also the Muslim populations of the Empire viewed a new war with Turkey, (e) the dangerous consequences of a new conflagration in the area of the oil-fields of Mesopotamia, and (f) the military weakness of the Empire, could all be regarded as factors responsible for the retreat of September 23. Therefore, the examination of these factors, as well as their interconnection, should be necessary; that is to say, the analysis of the needs, concerns and forces which formed this specific British decision.

However violent the explosion of Turkish Nationalism was -after the brutal interference and dismantling of the Ottoman Empire by the Great Powers- it would be very difficult to believe that the victors of World War I would submit to the demands of a defeated Turkey, if those victors were united. The dissension, however, between London and Paris about how they should face Germany, as well as the inconsistent policy about the division of the spoils in the Middle East, brought about such a break in the "Triple Entente" that France and Italy ${ }^{16}$ strove to undermine, in every possible way, the position of Great Britain in the Levant.

The split, indeed, between Great Britain and France constituted the most important factor for the British concession to the Nationalists. The latent breach with France over Germany radiated outwards throughout Europe to the borders, for French and British policies were most deeply and vitally opposed. The British need for the security of sea-communications implied instinctive opposition to any Power erecting a hegemony of force in Europe, while, in addition, the British need to trade implied a prosperous Germany. A prosperous Germany implied, in its turn, a politically stable and independent Germany. The creation of such a Government in that country was the essential and central requirement of British policy, the first condition on which the latter's national recovery was dependent. Such a goal, however, was one to which French policy

16. Italy's policy will not constitute an object of this study. It should be mentioned, however, that she followed the French anti-British policy, resented the way in which her Allies -and especially Great Britain- treated her after the end of war: they virtually revoked the Saint Jean de Maurienne Agreement (1 April 1917), about the territories of Asia Minor promised to her. 
and public opinion were deeply opposed. The grounds of this opposition were twofold. France needed to defend herself against the war of revenge which she feared Germany would undoubtedly organise, if this could be done with any prospect of success; France required immediate financial relief to save her national finances from bankruptcy ${ }^{17}$. These two demands combined, as vital and deep as British needs, could solidify French opinion at each recurrent crisis against the political and economic recovery of Germany - which the British on the whole were prepared to welcome. Nevertheless, neither of these demands were to be met, a fact that had the most negative consequences on the prompt and successful solution of the several problems which derived from the conflicting interests on the question of the proper settlement of the territories of the former Ottoman Empire.

The policy which Great Britain adopted immediately after the war was over ${ }^{18}$, changed the opinions on her that existed then in France ${ }^{19}$, caused much resentment and raised many questions about the usefulness of secret diplomacy followed at the time, and the diplomatic unity of the Allies ${ }^{20}$. The feeling that France had come off badly from the provisions of the Versailles Treaty, while Great Britain had taken all she wanted, was widespread. Franklin-Bouillon (Radical-Socialist deputy and Chairman of the Committee on Foreign Affairs), expressed-during the debate on the ratification of the Peace Treaty-this feeling as follows:

[:..] England had declared at the outset that she could not surrender her naval supremacy, whereupon this question, which had seemed likely to be the most difficult of all to settle between England and America, had simply vanished from

17. France found herself in a terrible situation after the ratification of the Peace Treaty for it left on her shoulders a debt of 175 billions of francs. As Briand (French statesman), however, said in an interview, given to a correspondent of the Journal, "People say that Germany will pay, but in the commissions dealing with this question, France has only one vote out of nine. The eight other parties, who have begun to resume commercial relations with Germany, will feel that it is to their interest not to weaken her. This means that France will receive but little". F.O. 371/3752, 120886/8259, G. Grahame (British Ambassador) to Curzon, Paris, 24 August 1919.

18. The good old era of Entente Cordiale was over. According to the British view, France was the Power Britain had most to fear in the future. As Lord Curzon warned: "She is powerful in almost all parts of the world, even round India": W. Stivers, Supremacy and Oil. Iraq. Turkey and the Anglo-American world order, 1918-1930, New York 1982, p. 26.

19. F.O. 371/2937, no. 80, Bertie of Thame to A. J. Balfour, Paris, 21 February 1917; F.O. 371/3219, 198213/no. 1654, Lord Derby to Foreign Office, Paris, 30 November 1918.

20. F.O. 371/3220, 168195/no. 1208, Lord Derby to Foreign Office, Paris, 6 October 1918. 
the programme. America declared that she could not live without the Monroe doctrine; everyone at once gave way on this point. Japan had threatened to withdraw from the Conference and refused to sign the treaty unless the 40 million Chinese of Shantung (a German colony) were handed over to her; the result was that, in the treaty creating the Society of Nations for the defence of the weak, the triumph of justice and the regeneration of the world, these 40 million men were duly handed over. What of France? France had presented the claims based on Marshal Foch's famous memorandum of the 22nd February, formulating the essential requirements for her safety; her Allies, having got what they wanted, had declared those claims unacceptable. French diplomacy had failed ${ }^{21}[\ldots]$.

This being the case, disagreements between France and her Allies were considered hostile actions towards her and they were explained on the grounds of jealousy and fear of "too great a France" : (a) the rejection - on the part of the London Government, along with that of Washington- of the French claims for infinite control of the Rhine bridgeheads and the occupation of Rhineland as long as might be necessary, and the extension of this occupation up to the basin of the Ruhr-with its minerals and its factories-as military guarantees of French security, (b) the denial of offering guarantees to France against a resuscitated Germany, regardless of whether the United States would ratify the treaty of joint AngloAmerican guarantee promised by Wilson and Lloyd George to Clemenceau in $1919^{23}$, (c) the objection of the British to the huge reparations demanded by the French $^{24}$, and (d) the consistent and strong opposition of the former to France's demand to hand over the industrial area of Upper Silesia ${ }^{25}$ to Poland ${ }^{26}$.

The British, for their part, refused to satisfy the French claims since any

21. F.O. 371/3752, 126386/8259, no. 872, G. Grahame to Curzon, Paris, 4 September 1919.

22. F.O. 371/3753, 181958/8259/17, Derby to Curzon, Paris, 27 February 1920.

23. F.O. 371/6998, W 9106/9106/17, Hardinge to Curzon, Paris, 22 August 1921.

24. At a meeting of the Supreme Council, held in Paris on the 26th January 1921, convened to consider the reparation question, P. Doumer (the French Minister of Finance) estimated Germany's total indebtedness as approximately 200 billions of gold marks. F.O. 371/8265, W 1389/1389/17, Hardinge to Curzon, Annual Report on France, 1921, Paris, 11 February 1922.

25. Such allocation to Poland would, moreover, result in a wholesale exodus out of the disputed area of the skilled workmen, who were practically all German. This procedure seemed to be according to the French interests, since it was understood that the French Government thought it possible to replace the German experts, who would leave the country, by Frenchmen. F.O. 371/5902, C 10337/92/18, Foreign Office memorandum on Upper Silesia Plebiscite, 19 May 1921.

26. F.O. 371/6995, W 6618/6298/17, Hardinge to Curzon, Paris, 3 June 1921; In order to be 
prolonged occupation of the Rhineland would leave France and Germany in a state which would be neither peace nor war $^{27}$-a state of affairs which could hardly lead to the recovery of the Continent-, and were strongly opposed not only to the reparation sums being fixed according to French demands, but also to their insistence of their payment, which would precipitate the crash of German economy. The City dreaded the prospect that the London finance houses, having financed German imports of food and raw materials, would have given their credits for nothing. This being the case, the British considered the moratorium on reparation payment an absolute necessity. The rationale for such a view was simple: the corollary was, if the German economy was broken, there would be a further violent depreciation of the franc, with the result that Great Britain would withdraw or curtail her credit to French enterprises, e.g. French railways. On the other hand, as far as Germany side was concerned, the German Government would make no further payments unless the Industrialists could find the necessary foreign exchange; the latter would only do that if they could receive credit in London; they could not, however, get credit there unless there was a moratorium, for London financiers regarded the position as hopeless ${ }^{28}$.

The most thorny problem, however, between the two allies remained the military guarantee, which was to be offered to France by Great Britain, against an unprovoked German attack. A feeling of insecurity prevailed among the French; and finally, found its expression in the proposal of a defence alliance between the two countries, which came to light as a result of an article in The Times of 3rd June 1921, regarding a possible Anglo-French alliance. The French

understandable the attitude of France on this question it would be necessary to be stated that Upper Silesia was a country richly endowed with minerals of various descriptions and of such value from a military point of view that General Ludendorff (Commander in chief, along with Hindeburg, of the Kaiserian army) in his book upon the Great War, described the mining areas of Upper Silesia as having made it possible for Germany to carry out a war of protracted duration, thereby, implying that without these districts it would be difficult for Germany to conduct a long war in the future. Public opinion and the French Government therefore resolutely set their minds of depriving Germany coute que coute of the industrial area of Upper Silesia, feeling that with control over the products of the Saar Valley, the industrial area of Upper Silesia in the hands of Poland and possibly with the Ruhr Valley in the hands or under the control of France, Germany would be deprived of all her rich industrial and mineral districts and would be helpless in the time of war. F.O. 371/8265, W 1389/1389/17, op. cit.

27. F.O. 371/3753, 181165/8259/17, Derby to Curzon, Paris, 25 February 1920.

28. F.O. 371/6039, C 22814/2740/18, Waterlow's memorandum on German reparation obligations and question of moratorium, 30 November 1921. 
did not lose the opportunity to bring before the British the question of closer cooperation -in the form of alliance- between the two countries in order to solve in an amicable atmosphere all the outstanding problems not only in Europe but all over the world ${ }^{29}$. The Paris Government maintained that the advantages of such a co-operation would be fourfold: (a) in the first place, France would be able to reduce her land armaments very greatly, and to advance towards the military disarmament for which the British had pleaded, (b) France would be reconciled to the immediate admission of Germany to the League of Nations, which would constitute an effective guarantee for a more pacific policy on her part in the future, (c) such an alliance would have a most stabilising effect on the Continent, and notably on Germany herself, who would think seriously before incurring the terrible risk of a revival of a war, and (d) it would enable France to join Great Britain and Germany in an attempt to reconstruct the shattered fabric of the Russian State ${ }^{30}$.

Nonetheless, the British, although admitting that the benefit of the suggested alliance with Europe was beyond question, were very sceptical about it. They never stopped taking into consideration the fact that the French, since the end of the war, had been actively pursuing a policy which was either unfriendly to British interests or, if not that, was bent on the promotion of French interests which were inconsistent with theirs. Moreover, they did not want to arouse any suspicion about revival of the old policy of State alliances -as it would be regarded in many quarters- with the objective of dominating and controlling the future of Europe.

29. As the French Ambassador, Le Comte de Saint-Aulaire -and the French Press as wellsuggested the British Government that the proposed alliance would rest on the principle that, while Great Britain would support French policy in Europe, and especially on German problem, France would support British policy throughout the rest of the world, and especially in the Middle East. F.0.371/6470, E 6462/1/44, Curzon to Hardinge, 13 July 1921; The British Ambassador informed Curzon, on 17th December 1921, that "Berthelot (Director General of the French Foreign Ministry) was quite open about it. He said that if we would support the French more on the Rhine, France would help us a great deal more in the East, recognising that the Rhine is the frontier of France and that the East is our frontier". C. Lowe - M. L. Dockrill, The Mirage of Power, vol. II: British Foreign Policy, 1914-1922, London, 1972, p. 367; The same, essentially, was proposed by Sir E. Crowe in a memorandum 6 months ago: "If we want France to stand by us and support our policy in the East, I am afraid we must bargain and pay [...] I believe France would pay a high price for an alliance by which we gave security against a German attack on the Rhine". D. Dakin, "Lord Curzon's policy towards Greece (1920-1923)", Essays in Memory of Basil Laourdas, Thessaloniki 1975 , p. 542.

30. F.O. 371/7000, W 12716/12716/17, Curzon to Hardinge, 5 December 1921. 
Apart from the above-mentioned, however, the British did not lose sight of the fact that they should be careful not to do anything that would lead Italy to think that she had been ostracised, or isolated, or turned out of an alliance which immensely flattered her national pride. The major problem, nevertheless, was the British themselves. What would the opinion of the British parliament, the British press, and the British public of such an entanglement be, and what would its effect on British policy throughout the world be? As Lord Curzon wrote in a memorandum, on 28 December 1921:

[...] A proposal by his Majesty's Government to commit this country to go to war again - not for a narrowly defined and easily intelligible object, such as the defence of the eastern frontier of France, which is also the external frontier of Britain- but for objects which will be difficult to define in words, and in contingencies which, though unlikely to arise, cannot be described as impossible, will, I think, excite in many quarters the gravest disappointment and alarm [...] There is a feeling of profound mistrust, if not worse, at the acceptance of fresh warlike commitments; this will be enhanced by the fear that a treaty of alliance with France may drag us into a war in which direct British interests are not involved $^{31}$, and which might have been avoided had not our ally encouraged to take up an unbending attitude, in regard to the particular matter, which constitutes the immediate casus belli by the knowledge that, in the event of rupture, British armed assistance was assured ${ }^{32}[\ldots]$.

This being the case, the British Government adopted Curzon's view -who thought it would be unwise to abandon the very powerful form of pressure, which the tactic of non-conclusion of the pact enabled them to exercise ${ }^{33}-$ and through the Foreign Office announced their decision that:

31. The French suggested that the proposed alliance would have to be in a double form, or to provide two stages, the one dealing with direct attack; the other with indirect attack. There was not any problem with the provision of "direct" attack, since-as it was natural-if the frontiers of France were crossed, the British nation would be at war with the aggressor. The problem had to do with the provision of "indirect" attack. Such a case might arise if a resuscitated Germany, in combination with a resuscitated Russia, decided to fall upon Poland. In such a case Britain would be obliged to take part in the conflict, although her interests were different and more remote, since the French would consider it equivalent to a direct attack upon their country. ibid.

32. F.O. 371/7000, W 13355/G, Curzon's memo on the Anglo-French alliance, 28 December 1921.

33. F.O. 371/8251, W 3150/50/17, Curzon's memo on the Anglo-French Pact, 17 February 1922. 
Before the conclusion of any form of pact with France, all outstanding difficulties between the two Governments should be discussed and satisfactorily settled ${ }^{34}$.

This decision on the part of the British ${ }^{35}$ caused much resentment across the Channel; the French press reacted bitterly after the announcement of nonconclusion of the pact, regarding this action as the possible withdrawal of Great Britain from her present alliance entailing her subsequent conclusion of agreements with other Powers ${ }^{36}$.

So, the failure of the French efforts to access Great Britain's co-operation in the settlement of the German problem giving her a free hand in the Middle East, and her dependence upon the British-American disposition for assistance, offended the French who discovered with frustration that although they had won the war they had lost the peace. This failure, attributed to the short-sighted policy of Great Britain, resulted in an "undeclared" war against her, the theatre of which was, this time, the possessions of the former Ottoman Empire.

It had become obvious in the course of the Peace Conference that the cornerstone of the eastern settlement, the Syrian question, was connected with the problem of the security of France as regards Germany, the extension of the latter's eastern boundaries included. France not being prepared to deal with the Arab problem, the promptness and the efficiency of British policy towards it, and additionally the overwhelming British military predominance over the Levant after the end of the war, created the preconditions of a conflict of the interests of the two western democracies. According to the agreements concluded during the war (Sykes-Picot, on May 1916 and Saint Jean de Maurienne, on April 1917), Syria, Cilicia and Lebanon were assigned to France, while the southern part of Mesopotamia, Baghdad included, to Great Britain; it had, additionally, been agreed that Palestine should be under international control. As these agreements, were the result of secret diplomacy without all the interested parties taking part in their formulation, it was impossible to put them into effect, without high level

34. F.O. 371/8251, W 3150/50/17, 4 April 1922.

35. There was, nevertheless, an opposite view besides the official one. That which considered the latter the same as "to put the cart before the horse", since no progress would be possible on that method, whereas, if the central question would be settled (i.e. the desirable security against Germany), all the other questions would be found easier at the periphery, or at least no worse. F.O. 371/7567, C 6200/6200/18, Waterlow's minute, 28 April 1922.

36. F.O. 371/8251, W 3900/50/17, Hardinge to Foreign Office, 8 May 1922. 
of co-operation between the Powers most interested in that area, namely Britain and France. Notwithstanding this precondition -the sine qua non one of any success of the plans for domination or tutelage over the Near and Middle Eastthe two western powers fought each other over the division of the spoils; as Colonel Lawrence said about the main agreement between Britain and France, i.e. that of Sykes-Picot:

Each party making the terms considered only what it could take, or rather what could be most difficult for her neighbours to take or refuse; the document is not the constitution of a new Asia, but a confession, almost an advertisement, of the greed of the conquerors. No single clause of it will stand the test of three years' practice $^{37}$.

The belief, nevertheless, that Russia would not be in any immediate position to exert any influence upon the Turkish settlement, and the refusal of the United States to assume responsibilities in the Near East, made France and Britain feel it safer to quarrel with each other rather than immediately to divide up amicably the spoils of the defeated enemy.

This being the case, the presence of huge British armies in the Levant unilaterally changed the Sykes-Picot agreement to the advantage of Great Britain $^{38}$ : Palestine and Mosul came under British control since, after Russia's withdrawal, it was no longer necessary to support the idea of internationalization in Palestine; besides, Russia's threat from Armenia no longer necessitated the abandoning of Mosul to the French ${ }^{39}$. Moreover, after the war was over, the British decided to detach Syria from the French control -although that area was considered hereditarily French domain-for the General Staff pronounced, that:

[...] from the strategic point of view, we should aim at a politically detached Syria

37. H. Cumming, Franco-British Rivalry in the Post War Near East. The Decline of French Influence, London 1938, p. 29.

38. In Lloyd George's view it was a settlement that "entirely overlooked the fact that our position in Turkey had been won by large British forces, whereas our allies had contributed but little to the result". W. Stivers, op. cit., p. 25.

39. J. Nevakivi, Britain, France and the Arab Middle East, 1914-1920, London 1969, p. 48; Since Russia was overwhelmed by revolution and had fallen out of the Great Power status, there was not reason any more for playing Mosul the role of a barrier in the path of Russian advance into the Middle East and Persian Gulf in particular. So, the deliberate British oversight regarding Mosul should be rectified. W. Stivers, op. cit., pp. 23-24. 
under our influence [...] Finally it is difficult to see how any arrangement could be more objectionable from the military point of view than the Sykes-Picot agreement, by which an enterprising and ambitious foreign power is placed on interior lines with reference to our position in the Middle East ${ }^{40}$.

The result of this decision was that the "Clapham Junction of the Imperial communications", as Sir Henry Wilson (Commander-in-Chief of the Imperial General Staff) once characterized Syria's vital significance to the British Empire, soon became a field of extreme tension between Britain and France. It would not be otherwise so long as the French Minister for Foreign Affairs, Stéphane J. M. Pichon, declared in the Chamber, on 29 December 1918, that France had historical rights in Syria, Lebanon, Cilicia and Palestine and, therefore, would not hesitate to enforce them ${ }^{41}$. The fact, however, that she had only fragmentary, though well qualified units in Arabia, a small detachment in Palestine, and a half-trained Syro-Armenian voluntary force in Cilicia ${ }^{42}$, whilst at the same time the Arabs regarded French predominance as wholly incompatible with the independence they had fought - or plotted-to gain, made the French position even more weak ${ }^{43}$. Furthermore, the French accused the British officials and officers of spreading propaganda all over the area assigned to France, with the purpose of opposing anything which might help to give the natives a right appreciation of France, or to cause her to be despised and hated by them, so long as she was alleged to be not only a minor Power, but the docile and selfeffacing subaltern of the British Empire ${ }^{44}$. On top of all this, the close

40. F.O. 371/4178, 13280/2117/44, Memorandum of the General Staff on the Strategic importance of Syria to the British Empire, 9 November 1918.

41. F.O. 371/4178, 2820/2117, no. 20, Wingate (Cairo) to Foreign Office, 5 January 1919.

42. An explanation for that weak military presence on the part of France in the Levant after the war was over, could be the fact that France, in the period from spring 1916 to autumn 1918, experienced four different cabinets, as well as that at the time of the most critical German offensive in the west front, from the end of March to the middle of July 1918 -when the very existence of France was at stake-could not be found but little interest in Paris for operations in the Middle East. Furthermore, at the final moment of the military effort and during the first phase of political persuasion in Syria and Palestine, her Government was led by Clemenceau who was by education, ideals and beliefs, much more inclined to occupy himself with national defence than colonial conquest. J. Nevakivi, op. cit., p. 65.

43. F.O. 371/4178, 7094/2117/44, Memorandum by D.G. Hogarth, 18 December 1918.

44. F.O. 371/4179, 49120/2117/44, Note upon the British aims in Asia Minor, communicated to Balfour by Pichon, Paris, 6 February 1919. 
relations between the Emir Feisal, son of King of Hedjaz -who proclaimed on October 3, 1918, an Arab Government in Syria- with the British, in conjunction with the disclosure that the latter made him a monthly allowance of $£ 200.000$, convinced the French that Feisal was a simple instrument of Britain; one more piece of evidence of the totally hostile action of the British towards them in the East $^{45}$.

Facing the challenge of their position in the Levant because of the overwhelming British military preponderance, the French continued to demand what had been assigned to them by the Sykes-Picot agreement, namely the unimpaired and total control over Syria and Mosul ${ }^{46}$. The former represented the whole moral edifice built up by them in the Levant from the time of the Crusades, consequently it was considered a matter of national pride ${ }^{47}$ not to make any concession in that region ${ }^{48}$. As regards the latter, it was not only the care of the Kurds -Mosul was their real capital- who were Christians and belonged ethnographically to the Indo-European race, which made the French think that it would be a great error on their part to allow them to be under Arab suzerainty, i.e. part of the Mesopotamian Kingdom under British control; the great wealth of petroleum deposits, many of which were quite near the surface, and other mining riches such as copper, antimony and even gold, were the main reasons for France defending her rights in that area ${ }^{49}$. That is why the latter raised the question of remaking a new agreement, in the case of Syria, Palestine and Mesopotamia, which would be more satisfactory to her than that of $1916^{50}$.

The British, however, had no desire to alter the status quo formed after the

45. Ibid.; see also H. Nicolson, Peacemaking, London 1933, pp. 139-141.

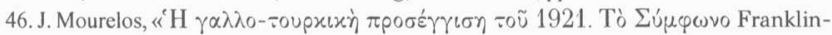

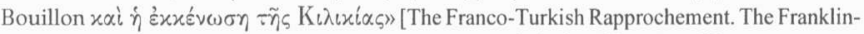

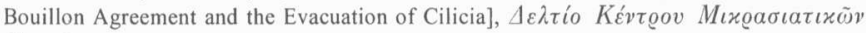
$\sum \pi 0 v \delta \tilde{\omega} v$, vol. 4 (1983), pp. 214-215.

47. It was not, of course, the alleged wounded national pride, the only reason for insisting the French on their "titles" over Syria. French capital had played a large part in developing road and rail communications in Syria. Ports and municipal enterprises like gas and electricity had been supported. The silk industry established in Lebanon and other industrial developments were promoted by French businessmen. A. Williams, Britain and France in the Middle East and North Africa, 1914-1967, London 1968, p. 6.

48. F.O. 371/4178, 4179, $11590,54702 / 2117 / 44$, Derby to Curzon, Paris, 16 January - 6 April 1919; F.O. 371/4178, 21612/2117/44, G. Grahame to Curzon, Paris, 6 February 1919.

49. F.O. 371/4179, 47891/2117/44, G. Grahame to Curzon, Paris, 25 March 1919.

50. F.O. 371/4179, 44731/2117/44, no. 540, Derby to Curzon, Paris, 20 March 1919. 
end of the war. So, one year after the deposition of Feisal and his total withdrawal from Syria ${ }^{51}$, the London Government, through W. Churchill (Secretary of State for the Colonies), announced, on 14th June 1921, their support to the candidature of the Emirs Feisal and Abdullah as rulers over Mesopotamia and Transjordania, respectively. This produced much bitter comment in France, who remained determined in her opposition to Feisal's election, in spite of assurances given by His Majesty's Government that no support would be given to him in any enterprise that he might contemplate against Syria ${ }^{52}$.

This being the case, it was not considered unnatural for the French to wage a severe anti-British propaganda war in the Levant with the purpose of undermining $^{53}$ the British position in Palestine, Mesopotamia and $\mathrm{Egypt}^{54}$.

The causes of friction, nevertheless, between Britain and France were not only confined to Europe and the Levant, but also extended to Africa and especially to Tangier. This city, being located at the entrance of the Mediterranean, was of high strategic and commercial importance to Britain, and for that reason she insisted on its internationalisation, as long as it was accepted that:

[If Tangier was controlled by a hostile Power] [...] the British position in the Mediterranean would be very seriously menaced, and the effect would extend to our Indian and Eastern possessions. The value of Gibraltar to Great Britain, which largely depends on the denial of that fortress to a possible enemy, would tend to disappear altogether [Thus] [...] our advantage lies in maintaining Tangier as an undefended port unsuitable for naval use. This can be best secured by Tangier remaining under international control of France, Spain and Great Britain $^{55}[\ldots]$.

The French, however, did not accept the aforesaid British claim, maintaining

51. F.O. 371/6998, W 8800/8800/17, Hardinge to Curzon, Annual Report on France, 1920, paras. $211-223$.

52. F.O. 371/6344, E 7125/7125/65, Hardinge to Curzon, Paris, 19 June 1921; Annual Report on France, 1921, op. cit., paras. 40-42.

53. The new cabinet which was formed after Clemenceau's resignation, adopted a different policy-line; rather than to secure France's Middle East interests proclaimed herself advocate of Turkey's integrity. J. Mourelos, op. cit., p. 216.

54. F.O. 371/6458, E 1815 - E 12929/121/89, Major Ormby-Gore (M.P.) to Harmsworth (Under-Secretary of State for Foreign Affairs) - Hardinge to Bonnevay (Acting Prime Minister and Minister for Foreign Affairs), 8 February - 23 November 1921.

55. F.O. 371/8343, W 2207/197/28, Memo by G. H. Villiers on Tangier, 10 March 1922. 
that, although they had agreed, in 1914, on the terms of the "Statut spécial de Tanger", they did so only because they were tied up by the Act of Algeciras ( 7 April 1906), by the Franco-German Convention of 1911, and fear of Germany. So, they contended that, since the Treaty of Versailles swept away the abovementioned accords and all German obligations, the French Government was bound to carry out the terms of the various treaties and conventions, which never referred specifically to internationalisation, but only to a "régime" or "caractère spécial". This contention caused a strong reaction on the part of the British, who protested that:

[...] The obligation to agree to internationalisation rested on definite French engagements to His Majesty's Government which the French could not honourably evade, and in return for which they had received their quid pro quo, i.e. our adherence to the Franco-German Convention of 1911 and our recognition of the French protectorate ${ }^{56}$.

It had already been more than obvious that the Tangier question, presenting "certain difficulties", as Poincaré said, would serve, for many years to come, to incite friction between Britain and France ${ }^{57}$.

This being the $\operatorname{case}^{58}$, the presence of the Greek army in Asia Minor was faced with hostility, so long as it was thought to be acting as an instrument ${ }^{59}$ or worse as a "cat's-paw" of the British policy in the Eastern Mediterranean.

56. Ibid.

57. F.O. 371/8244, W 528/50/17, Minute by Villiers, 17 January 1922.

58. It is characteristic that Clemenceau, a lifelong exponent of co-operation with Britain, remarked privately: "England is the lost illusion of my life! Not a day passes that I do not receive from one of our agents abroad reports indicating veritably hostile acts. I had hoped that the fraternity of arms [...] would suppress the old traditional prejudices. Not at all. The evil is without remedy". G. Wright, France in Modern Times, 1760 to the present, London 1962, pp. 437-438.

59. F.O. 371/7869, E 646/5/44, Cheetham to Foreign Office, Paris, 1 August 1922; Besides, Poincaré (French Prime Minister) stated to an American publicist, in late July 1922, that: " [...] France do not oppose Greece by reason of Greece herself, but because Greece is acting as an agent of Great Britain in the Levant and moreover that France could not bear British prevalence at Constantinople [...]". A.Y.E., 1922, A/5/VI (9), 2533, Ragavis to Foreign Ministry, London, 2 August 1922; Revealing, to this effect, could be considered the report which was submitted to a foreign High Commissioner, under the title "La politique française en Turquie". A.Y.E., 1922, A/5/VI , 4129 , Triantafyllakos (High Commissioner) to Foreign Ministry, Constantinople, 13 August 1922.

60. F.O. 371/7585, C 12094/13/19, Bentinck to Curzon, Athens, 8 August 1922. 
Its expulsion, therefore, not only out of Smyrna but from Eastern Thrace as well, was considered imperative, since it would be detrimental to British interests in the area. For that reason, the Paris Government had been very helpful to Kemal offering him not only diplomatic support ${ }^{61}$ but also saving him from one more front, after the retirement of the French troops from Cilicia, as a result of the Franklin-Bouillon agreement on 20 October $1921^{62}$. The French support of the Nationalists ${ }^{63}$, however, did not stop at that point; it was a common secret that France was providing the Nationalists with guns ${ }^{64}$, going so far as to hand over munitions to them from the Turkish stores at Constantinople, which were under their guard ${ }^{65}$.

So, after the collapse of the Greek front and the appearance of the Turkish army at Chanak, Poincaré, attempting, on the one hand to increase the prestige and negotiating position of France towards Kemalist Turkey ${ }^{66}$, as well as to

61. F.O. 371/7856, E 2065/5/44, Rumbold to Foreign Office, Constantinople, 21 February 1922.

62. S. R. Sonyel, Turkish Diplomacy, 1918-1923. Mustafa Kemal and the Turkish National Movement, London 1975, p. 138; For a detailed account about Franklin-Bouillon agreement, J. Mourelos, op. cit., pp. 227-243.

63. Twice, nevertheless, there was reverse of French opinion against the Turks and in favour of Greece. The first time, because of the conditions imposed by the Nationalists on the French in order to ratify the Franco-Turkish treaty concluded in March 1921, and because of rejection of the French proposals concerning Cilicia followed by Turkish advance towards Aleppo. The second time, when was realised by the French that Kemal's army was not all powerful as they had believed. F.O. 371/6470, E 6157/1/44, Hardinge to Curzon, Paris, 28 May 1921; F.O. 371/7867, E 6440/5/44, Malcolm to Harmsworth (without place), 28 June 1922.

64. F.O. 371/6475, E 10966/1/44, Rumbold to Curzon, Constantinople, 28 September 1921; A.Y.E., 1922, A/5/VI ${ }_{(31)}, 285$ - I. L. 2/785 - 8685/II/23638 - 728, Triantafyllakos - Dousmanis (Rear Admiral) to Foreign Ministry - Chatzianestis (Field Marshal) to War Ministry - Kolovos (second secretary of the Vice-Consulate in Pyrgos) to Foreign Ministry, 29 April - 4 May - 10-18 August 1922; H. R. Davison, "Turkish Diplomacy from Mudros to Lausanne" in Diplomats, 19191939, ed. by A. G. Craig - F. Gilbert, vol. I, New Jersey, 1953, p. 193; D. Dakin, op. cit., p. 542; The French, leaving Cilicia, handed over all their arms and munitions to the Nationalists. J. Mourelos, op. cit., pp. 257-262.

65. F.O. 371/7858, E 3282/5/44, Harington to the Secretary of War, Constantinople, 10 March 1922; D.B.F.P., XVII, no 746; As Rumbold reported, it was not strange that it could be kept nothing secret from the Turks, so long as Pellé (The French High Commissioner at Constantinople) diclosed to the Nationalists whatever was being discussed in High Commissioners' meetings and he delivered them whatever memoranda were being exchanged amongst their Governments. F.O. 371/7871, E 8425/5/44, Rumbold to Oliphant, 15 August 1922.

66. France had great financial interests in Turkey than any other country: French bondholders, 
Muslim World ${ }^{67}$ and, on the other hand, to undermine British policy in the Eastern Mediterranean, he totally identified himself with Kemal's demands for the immediate handing over of Eastern Thrace to the Turks. As the French Prime Minister explained to Curzon on September 20, the information that a revolution was imminent in Eastern Thrace ${ }^{68}$, if the Allies did not satisfy that demand, influenced his decision not to expose the French troops to the danger of fighting against the Nationalists. Moreover, he did not conceal his anxiety about the safety of the French colony in Constantinople which would undergo Turkish savagery, unless all the desired concessions were met ${ }^{69}$.

according to Berthelot, held $80 \%$ of the Ottoman debt of $£ 144$ million and there was a good deal of French money invested in various enterprises in Turkey. Since the French investors had lost all the immense sums they had lent to Czarist Russia, Millerand and Poincaré administrations -more susceptible to the pressures by the powerful financial circles- wanted to secure at all costs, at least, the repayment of the Ottoman debt. D. Lloyd George, op. cit., p. 1273; J. Mourelos, op. cit, p. 212; Besides, good relations with Turkey would be most conducive to French interests. The Turkish Government, which had marched from Ankara to Constantinople with the goodwill of France, would have much to give. W. S. Churchill, op. cit., p. 41 I; It should be pointed out, however, that one more reason for the expulsion of the Greeks from Asia Minor was the fact that, being the Greek middle class the dominating element in Turkey, it would constitute tough and dangerous rival to economic and commercial interests of France. Therefore, the target could not be other than its etimination, so that the Western Capital to enter direct business with Nationalist Turkey - policy

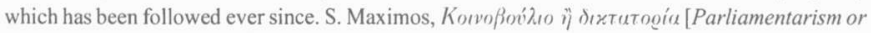
Dictatorship], Athens $1975^{2}$, p. 25.

67. As regards the relations between Paris and Muslim world, Poincaré -trying to justify the French consent to all Turkish demands- stated in a speech addressed at Vau Coulers, on 8 October, that France was a great Power with large Muslim populations, whose attitute and susceptibilities could not but influence the Eastern policy of France. Besides, if Eastern Thrace had been refused to the Turks, it would be possible the hostilities to be prolonged and moreover a general islamic rising to be provoked. F.O. 371/7900, E 10716/27/44, Hardinge to Foreign Office, Paris, 8 October 1922.

68. France would not have to be afraid of any rising, if she had not created herself the preconditions for its outbreak: By mid summer 1922, the French distributed guns and grenades to the Muslim populations behind Chatalja line. On September 1922, it has been known that the French military mission at Sofia was encouraging Bulgaria to take advantage of the situation and make troubles for Greece in Thrace, calling moreover on Turks of Macedonia to join Bulgarian in shaking off Greek yoke and forming autonomous Macedonia in conjuction with Kemal. A.Y.E. 1922, A/5/VI , , П. 471, X. Simopoulos (Acting High Commissioner) to Foreign Ministry, Constantinople, 25 July 1922; F.O. 371/7888, E 9319/27/44, Bentinck to Foreign Office, Athens, 13 September 1922.

69. D.B.F.P., XVIII, nos. $42,51$. 
Great Britain, therefore, found herself in a very awkward position. If her Allies did not join forces with her, she would have to face and stop the Nationalists alone. Did she, however, have the strength to take such a dangerous and audacious action? The resolution of 15th August 1919 -known as "Ten Years Rule"- which stipulated that the British Empire would not be engaged in any great war during the next ten years, weakened her military power considerably ${ }^{70}$. For the first time, after many generations, the balance between her military power and the magnitude of her commitments was disturbed ${ }^{71}$. As the naval policy was set in the direction of reduction and retrenchment ${ }^{72}$, the inability to adopt a power policy - which unavoidably would lead to war-- was consequent.

Furthermore, the refusal of India and Dominions -with the sole exception of New Zealand, which offered a battalion ${ }^{73}$ - to send troops to reinforce the British positions at the Straits, increased the problem and made it clear that Britain was not militarily prepared to meet the Kemalist threat in the Dardanelles and in Iraq simultaneously. (The possibility of Kemalist attack against Iraq will be examined below.) The British Government, however, was confronted with serious difficulties in another quarter as well; the situation in Egypt, because of the development of the Nationalist movement, was far from good and as Murray wrote on 9 October 1922, an Anglo-Turkish conflict would possibly endanger the British position in Egypt:

[...] In view of possibility that his Majesty's Government may suddenly find themselves engaged in military and naval operations against the Turks, I venture to submit that the effect of such a conflict on our position in Egypt should be considered [because] [...] the occurrence of such a crisis, which would be hailed

70. B. Bond, British Military Policy between the two World Wars, Oxford 1980, pp. 23-27.

71. Sir Henry Wilson was very worried about the gap between British power and British responsibilities. As he wrote to Admiral Cowan, in April 1919 (in C. E. Callwell, Field Marshal Sir Henry Wilson. His Life and Letters, vol. II, London 1927, p. 182): "My whole energies are now bent to getting our troops out of Europe and Russia and concentrating all our strength in our coming storm centres, viz. England, Ireland, Egypt and India". D. R. Watson, "The Making of the Treaty of Versailles", Troubled Neighbours, ed. by Neville Waites. London 1971, p. 76; B. Bond, op. cit., p. 10.

72. It is characteristic that in winter of 1922 the number of the forces of the Royal Navy had been reduced to such a level that for first time it was made impossible for Christmas leave to be

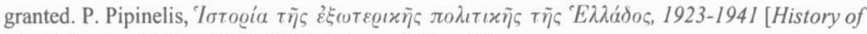
Greek Foreign Policy, 1923-1941], Athens 1948, p. 119.

73. B. C. Busch, op. cit., p. 348. 
as a British disaster, would of itself create a dangerous atmosphere in this country [...] If, moreover, the crisis [at the Straits] is a grave one, it might be necessary temporarily to deplete the garrison [...] it would therefore be necessary to decide whether to run the risk of leaving a weak garrison of one or two battalions in Cairo, where they would be cut off by anything in the nature of a general rising; or to withdraw British troops to the canal zone and Alexandria, where isolation would be impossible. The adoption of the second alternative would be the least risky course, but it would involve imposing on the Egyptian Government the entire responsibility for maintaining order in the interior of the country, and if they proved successful, they would be in a position to argue with much force that the presence of British troops outside Alexandria and the canal zone had been shown to be unnecessary ${ }^{74}$.

Besides the military deadlock, however, the British Government also experienced stiff pressure from the public opinion, which was definitely opposed to war. The average Briton was not prepared to fire another shot for any cause ${ }^{75}$. In addition, after the Greek defeat, there was a resurgence in the Conservative breast of the old admiration for the Turks and their masterful ways with the subject races; nevertheless, the fact that the majority of the Cabinet and the General Staff was pro-Turk, rendered very difficult the prolonging of Lloyd George's anti-Turkish policy ${ }^{76}$.

On the other hand, the British Empire - being the greatest Muslim power in the world-could not ignore or even offend the religious feelings of more than 70 million Muslims in India. Besides, the pressure exerted by the Indian Muslims and the wish on the part of the British not to provoke their religious feelings and finally not to endanger their position in India ${ }^{77}$ as well as in the Islamic world, was the other most important factor which forced the London Government to agree to the Nationalists' demands.

74. F.O. 371/7900, E 10681/27/44, Minute by Murray, 9 October 1922.

75. D. Lloyd George, op. cit, p. 1350; B. Bond, op. cit., p. 35; A. Toynbee, The Western Question in Greece and Turkey, New York $1970^{2}$, p. 59.

76. A.Y.E., 1922, A/5/VI , 3136, Ragavis to Foreign Ministry, London, 24 September 1922; D. Lloyd George, op. cit., p. 1350; W. S. Churchill, op. cit., p. 391.

77. Great Britain's economic interests at stake were so great that Muhammad Ali (one of Khilafat's movement leader) said in a speech in Madras, on April 2, 1921: "[...] A shot fired from Madras kills [the British textile industry in] Manchester". G. Minault, The Khilafat Movement. Religious Symbolism and Political Mobilization in India, New York 1982, p. 133. 
Since the end of the war the Indian Muslims had continued to plead, pass resolutions, and put pressure -especially through the "Khilafat Movement"- on the Metropolitan Government that it should not antagonise the Muslims, nor deprive Turkey of Eastern Thrace and Asia Minor, and leave intact the temporal and the spiritual power of the Caliph in Constantinople ${ }^{78}$, otherwise they would support their Caliph against his enemies, severing all relations of loyalty with Great Britain, while any unfavourable arrangement regarding the Turkish territory and the position of the Caliph would be considered as an aggressive act against Islam itself ${ }^{79}$.

This being the case, the Viceroy informed the Government that -apart from the resolutions and speeches which were mainly an hysterical outburst of a highly emotional people- the most alarming fact was the open expression of disloyalty, although conditional, which might lead to local disorder. At the end of 1920, constant deterioration of the political situation in India made him urge that the Sultan's suzerainty, at least over the holy places (e.g. Hedjaz), should be recognised ${ }^{80}$.

It did not escape the attention of the British, however, that the Khilafat movement covered the real scope of the Indian Muslims, in combination with Hindus, which was the final liberation of India ${ }^{81}$. On the other hand, the Indian Muslims, standing with the Kemalist movement, continued to accuse the British of helping the Greeks in their offensive against the Turks, whilst they spread the

78. F.O. 371/5140, E 490/139/44, Abdul-Bari to Curzon, Lucknow, 30 January 1920; F.O. 371/5140, E 139 - 477/139/44, Anglo-Ottoman Society to Curzon - H. R. Syed Abdul Majid (Islamic Society, London), to Foreign Office, 18-22 February 1920; F.O. 371/5140, E 1102/139/44, Abulkalam Azad (President of Bengal Khilafat Conference) to Curzon, Calcutta, 1 March 1920; B. C. Busch, op. cit., p. 330.

79. F.O. 371/5140, E 1128/139/44, A. C. Wratislaw (Consul-General) to Curzon, Beirut, 18 February 1920; F.O. 371/5141, E 3782/139/44, Islamic Society's resolution, 25 April 1920; F.O. 371/5142, E 8907/139/44, Council of all India Muslim League to Prime Minister, Lucknow, received 27 July 1920.

80. F.O. 371/5140, E 2031/139/44, Viceroy to India Office, 7 March 1920; F.O. 371/5142, E14951/139/44, Viceroy to India Office, 23 November 1920.

81. F.O. 371/6549, E 1013/347/44, Shuckburgh (India Office) to Oliphant (Foreign Office), Memo by Major Bray (Political Intelligence officer attached to India Office) under the litle "The Indian Khilafat Delegation", 18 January 1921; G. Minault, op. cit., p. 110; Munir Ahmad Baluch,

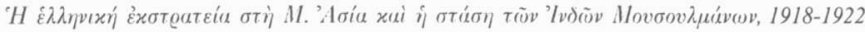
[The Greek Expedition in Asia Minor and the Role of Indian Muslims, 1918-1922], Ph. D., Thessaloniki 1987, pp. 83-85, 93. 
rumour that only Britain, unlike France and Italy, was opposed to the modification of the Peace Treaty ${ }^{82}$-that is the restoration of Smyrna and Thrace to the Turks- thus increasing the humiliation of the Caliph and Islam as well.

Although the employment of counter-propaganda on the part of His Majesty's Government towards the Caliphate was proposed ${ }^{83}$, soon it was understood that, under those circumstances, it would be beside the point; for the pro-Turk agitation did not derive from the Indian Muslims' liking for the Turks -they were no more enamoured of them than the Egyptians or the Syrians- but from the concept they held about the nature of Islam and the mission of the Caliph in Constantinople: the Muslims believed that the Head of the Faith must be free and independent. The Arab King of the Hedjaz was not considered by them free and independent, nor was the Emir Feisal (both were under British tutelage), nor was Mulay Youssef, Sultan of Morocco (under the French protectorate). For that reason they looked to Turkey as the Power that had for years been the bulwark of Islam in dealing with the Western Powers and they were convinced, on grounds of emotion rather than of reason, that Islam could not permit Turkey to be relegated to the position of a third rate power, so long as she was the only country that could give them the free independent Caliph required by their faith ${ }^{84}$. Moreover the Indian Muslims' attitude towards Turkey was strongly connected to their position in India, as well as their relations with Hindus. On that; Howell was very clear, writing that:

[...] The attitude of Muslims in India vis-à-vis Hindus had always been one of pride and superiority in their many differences. They had lost no opportunity of impressing on Hindus that whatever might be the local and numerical importance of Hindus in India, their position could not compare with that of Muslims. For Islam was a World Power; their Caliph was the secular ruler not only of a kingdom of Asiatic importance, but of considerable influence and prestige in Europe $^{85}[\ldots]$

82. F.O. 371/5141, E 3430/139/44, Islamic Society's resolution, 15 April 1920; F.O. 371/6549, E 991/347/44, P. 424, Viceroy to India Office, 18 January 1921; F.O. 371/6508, E 4170/143/44, P. 1785, Viceroy to India Office, 5 April 1921.

83. F.O. 371/7858, E 3405/5/44, Memorandum by Mr. Ryan suggesting lines of a counterpropaganda against the "Caliphate" and similar agitations, 26 March 1922.

84. F.O. 371/8351, W 1826/1375/28, A. Robertson to Curzon, Tangier, 14 February 1922; F.O. 371/7867, E $6937 / 5 / 44$, E. B. Howell (for Secretary to the Government to India) to India Office, Simla, 25 April 1922.

85. F.O. 371/7867, E 6937/5/44, op. cit. 
To this effect, Turkey's reduction to insignificance would be considered a fatal blow to the prestige, influence and strength of Islam as a whole ${ }^{86}$.

This being the case, the Viceroy, on 26th January 1921, expressed himself openly in favour of the Treaty's revision for preserving tranquillity in India ${ }^{87}$. By June of the same year he warned that constant support to the Greeks might cause embarrassing and dangerous agitation in the country, whilst in October he suggested the immediate return of Eastern Thrace to the Turks, as the only means of restoring British influence in the Muslim world ${ }^{88}$. After one year, on 11 September 1922, the Viceroy submitted a colourful account of the conditions in India, causing serious doubts about the continuation of the peace and unity of the Empire:

A Graeco-Turkish crisis must be expected to cause violent repercussion through the Islamic world, and may add considerably to our difficulties in India, on the North-West frontier and Afghanistan. We, therefore, earnestly beg that His Majesty's Government will give every possible weight to India's interest before

86. In spite, however, the widespread concept among the Indian Muslims that the Ottoman Sultan was the Calipha, viz. the leader of all the Muslims, the Arabs themselves rebutted such an idea describing it as flatly contrary to History. So, they maintained that the Mohammedans of Hedjaz and of Morocco looked to their own Sherrifs as their spiritual heads; the Shias believed the Khilafat to belong to the twelfth Imam, and the Wahabis of Central Arabia did not recognised the Ottoman Sultan as Calipha..According to Professor Jadunath Sarkar, who was an eminent authority on the Mongul period, the most orthodox of the Mongul Emperors did not acknoweledge the spiritual headship of the Sultans of Turkey, the Koranic concept being that the Muslim ruler of a Mohammedan kingdom was himself the only person whom his subjects could regard as Caliph. In his correspondence with the Sultan of Turkey, Aurungzed, never hailed the latter as "Calipha", but as "Caesar of Rome". The fact that this Caesar of Rome was in possession of the Holy Places of Islam, was apparently irrelevant to any claim on his part to universal Khilafat. Similarly, Shah Jedan never acknowledged the Sultan of his day as Caliph or Viceregent of God. Professor Sarkar summed up the position as follows: "In short, the theory that the Muslim ruler of Turkey is the spiritual Head of all the Mohammedans, wherever they may live, is a creation of the late nineteenth century, and merely a result of the growth of a political pan-islamic movement as a natural reaction against steady absorption of all Sovereign Islamic States by the Christians". F.O. 371/5141, E $3090 / 139 / 44$, H. McPherson (Secretary to the Government of India) to the local Government (without place), 10 February 1920.

87. F.O. 371/6549, E 1441/347/44, Viceroy to India Office, 26 January 1921.

88. Cabinet Papers (=Cab.) 24/125, C.P. 3092, 23 June 1921; Cab. 24/129, C.P. 3412, 11 October 1921. 
reaching their decision [...] From India's standpoint, the essential thing is the restoration of the old cordial relations between Great Britain and Turkey [...] Even if it [the concurrence to the Turkish demands] should involve re-adjustment in our general Arabian policy, this would be compensated for by increased stability, the cutting down of our own commitments and eventual restoration of our general prestige and influence throughout the East. On the other hand, any attempt to rob the Turks of the legitimate fruits of their victory would awaken a storm much greater than before throughout Islam, and might probably involve serious consequences to India ${ }^{\mathrm{x} 9}$.

Despite the gloomy prediction, however, it was generally admitted -a view which Curzon himself adopted-that the pan-Islamic movement which favoured Kemal, was artificial ${ }^{90}$; nevertheless, despite opposition from the Prime Minister and the Foreign Secretary, the British Government could ignore neither the grave situation in India ${ }^{91}$ nor the negative consequences of the appearance of a Muslim movement, regarding the preserve of the Empire's predominant role over the Near and Middle East ${ }^{92}$.

In fact, the decisive zeal of Indian Muslims in favour of the Turks, in combination with the persistence of Kemalists in identifying Britain with the presence of the Greeks in Asia Minor, put the London Government in an untenable position, not only in India itself but in Mesopotamia as well (i.e. Iraq), where her position had not yet been secured, since a general Muslim rising could jeopardise her interests in the area. Besides, the India Office had noted earlier that there were important commercial and strategic interests in the Middle East

89. Cab. 24/138, C.P. 4186,11 September 1922.

90. F.O. 371/7864, E 5139/5/44, Letter which was given to Harold Buxton (English Correspondent), who, in his turn, sent it to Under-Secretary of State for Foreign Affairs, Constantinople, 1 May 1922; H. Nicolson, Curzon: The Last Phase, 1919-1925: A Study in PostWar Diplomacy, London 1939, p. 99; B. C. Busch, op. cit., p. 328; Munir Ahmad Baluch, op. cit., p. 40.

91. It was characteristic of the highly strained situation in that country that, after the collapse of Greek front in Asia Minor, the military authorities of India recommended the Government in London that, as the existence of British material among the captures from Greeks could be used by the Turks as a proof of British assistance to the Greeks, it was advisable that Reuters should be prevented from wiring such a report to India. F.O. 371/7889, E 9495/27/44, Chief of Staff (India) to War Office, 14 September 1922.

92. F.O. 371/8084, N 8433/8433/97, Abdul Hadi (Afghanistan's Minister in London) to Curzon, 11 September 1922. 
for India and declared that a barricade should be set up in Mesopotamia which would effectually protect the landline of the Gulf from any potential enemy of the British Empire ${ }^{93}$.

In September 1922, however, it was not a matter of a potential enemy but of a victorious nationalist movement, which aimed to regain its most historical territories, including Mosul ${ }^{94}$. By September 1921, Churchill (Secretary of State for the Colonies) had referred to the possibility of Kemal's attacking this area, in case the operations in Western Asia Minor came to a state of stalemate; in that event, he estimated that, repelling the enemy would cost at least 5 or 6 million pounds, whilst, at worst, they would be compelled to give up the Mosul Vilayet altogether $^{95}$. His estimates, indeed, were correct; on 18th September 1922, King Feisal of Iraq informed the British High Commissioner that he was afraid that Kemal would immediately move against Iraq, if the Dardanelles question led to a state of war between Great Britain and Turkey ${ }^{96}$. This information could not have been more alarming; the Secretary of the State for War, L.W. Evans, in November 1921 , in a memorandum to the Cabinet had admitted that the preservation of the British presence in Iraq and Palestine depended upon peace in Mosul ${ }^{97}$; were the Turks to be in possession of Kurdistan and Mosul Vilayet, the small British garrison at Baghdad would be in a most exposed position thus rendering its forced withdrawal from this city - with the Turks better placed to stir up rebellion in Iraqa most difficult and dangerous operation ${ }^{98}$.

Apart from the necessity of securing the Empire's positions in Iraq and generally in the Middle East, London never wished to be involved in a battle with

93. F.O. 371/3756, 173183, D. 238, Indian Office memorandum under the title "Indian Desiderata for Peace Settlement", 4 December 1918; K. Jeffery, The British Army and the Crisis of Empire, 1918-1922, Manchester 1984, p. 37.

94. The British had been informed on good authority that it was not only the French but the Americans as well who regarded not unfavourably a Turkish attempt at the reconquest of Mosul and the whole of Iraq. Regarding the French, the profits of such a policy would be not only economic (priority rights in the oil of Mosul and the concession for the Baghdad railway) but political as well. If the Turks returned to Iraq the French administration in Syria might appear relatively liberal and pro-Arab, and, moreover, the French would be rid of Feisal whom they regarded hankering after a throne in Damascus. F.O. 371/6347, E 14134/43/93, C.P. 3566, Secretary of State for the Colonies to the Cabinet, 13 December 1921.

95. Cab. 24/128, C.P. 3328, 26 September 1921.

96. Cab. 24/138, C.P. 4198 , 18 September 1922.

97. Cab. $24 / 129$, C.P. 3474,9 November 1921.

98. War Office (=W.O.) 33/1016, A 2495, 19 October 1922. 
the Turks for one other reason: oil, which was the main reason for the violation of Sykes-Picot agreement on the part of Great Britain. Although the Iraqi oil was not brought into production until 1927 , it was natural for Iraq and especially Mosul to occupy a major place in British diplomatic and military concerns in the Middle East, since the Admiralty discovered, in August 1918, that it would need the entire oil production of that region after the $\operatorname{war}^{99}$. Given the abovementioned, the view that the stable condition on the Northern frontiers of Iraq as well as the British presence in the area would be secured ${ }^{100}$, only if favourable peace terms were offered to Kemal, did not constitute favourable preconditions for the solution of Eastern Thrace's problem as far as Greek expectations were concerned.

The fact that Soviet Russia offered generous assistance to the Nationalists ${ }^{101}$ did not weigh less in Great Britain's decision to yield to the Turks ${ }^{102}$. The first communist country -in her endeavour to consolidate her position and to promote friendly relations with its neighbours, by helping to save them from imperialism- approached Kemal and contributed so decisively to the realization of his national programme, that Turkey remained the keystone of Soviet policy in the

99. C. Lowe - M. L. Dockrill, op. cit., p. 357; M. Kent, Oil and Empire British Policy and Mesopotamian Oil, 1900-1920, London 1976, p. 14; Great Britain's intention to secure her access to the Mesopotamian oil was pointed out by the reports of the special American mission at Lausanne: "[...] There is some reason to believe that the policy of Great Britain, backed by the general attitude of the Conservatives in England, might seek withdrawal from Mesopotamia in return for advantages with respect to concessions, especially in the matter of petroleum[...]". Foreign Relations of the United States 1922, vol. II, no. 24, Washington 1938.

100. W.O. 33/1016, op. cit.

101. It was well known that the Soviets granted huge amounts not only to the Turkish Nationalists but also for the formation of a League for the liberation of all Mussulman territories under European domination, especially those under British control. F.O. 371/5220, E 6024/1942/44, Sir P. Cox (British Minister) to Curzon, Teheran, 17 April 1920; F.O. 371/6465, E 1717/1/44, Department of Overseas Trade to Foreign Office, 7 February 1921; F.O. 371/6345, E $13559 / 13559 / 65$, India Office to Foreign Office, Memo on the continuing encourage granted by the Soviets to the Muslims for continuance of hostilities against Great Britain, 9 December 1921; S. R. Sonyel, op. cit., p. 175.

102. The Kemalist-Bolshevist rapprochement influenced a great deal the French policy not only vis-à-vis the Cilicia problem but as well as regarding her relations with Nationalists. Paris Government considered the close Russo-Turkish relations as a serious obstacle to an eventual Franco-Turkish approach. If it did happened so, she would lose the priveleges -economic and political-, which she would obtain as the first European Power concluding an agreement with Kemalist Turkey. J. Mourelos, op. cit., p. 219. 
Near and Middle East until $1923^{103}$. The explanation of the Soviet stance should not be seen only in the light of political theories and moral principles, but in the sense that the adoptation of a pro-Turk policy seemed to open up positive prospects to promote her interests: the Kemalists were the best organised, strong and most promising national movement in Asia, which unavoidably would contribute to her own strengthening and recognition of her importance in the world diplomatic arena. Moreover, the possession of the Straits by the Turks would secure the unimpeded continuation of vital grain imports and in general the expansion of Soviet trade, without any interference from the British Admiralty. Another relevant factor was the danger which could be posed by the presence of a strong Greece which, dominating the Eastern Mediterranean, would impede the access of the Soviets to that Sea, whereas at the same time she [Greece] would cover the British Empire's communication line with India ${ }^{104}$. To this effect, the Soviet view, which was contrary to that of the British, was clear: the Turks should gain footing in Europe or control the Dardanelles ${ }^{105}$.

Soviet Russia, having suffered the results of free entrance of foreign ships into the Black Sea during the civil war, had become an enthusiastic advocate of Turkish control over the Straits, unlike Great Britain which was not alarmed by the Russian fleet any more, but aimed to restrict Turkish control over the Dardanelles and to safeguard the unimpeded entrance and exit of warships of all the nations ${ }^{106}$.

For that reason on 12 September 1922 the Soviets informed the British Government that they would not recognize any decision regarding the Straits taken in the absence of the Black Sea States ${ }^{107}$. By virtue of that decision, therefore,

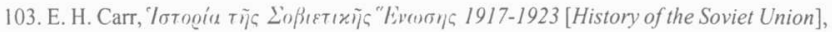
vol. 3, Athens 1982, p. 575; The Soviet Government granted precious assistance to Turkey, going so far as to ignore even the needs of her people. As Ali Fuad (First Turkey's Ambassador in Moscow) stated, in 1958, the Soviet Government-besides 10 million gold roubles- supplied the Kemalists, during the period of national struggle, with large quantities of guns enough to arm three divisions. H. Kapur, Soviet Russia and Asia, 1917-1927, Geneva 1966, p. 114.

104. D. Zapantis, Greek-Soviet Relations, 1917-1941, New York 1982, p. 55; H. Kapur, op. cit., p. 123.

105. D.B.F.P., XVIII, no. 38.

106. About the different point of views on the part of Great Britain and the Soviet Union regarding the freedom of the Straits, see H. Nicolson's Memorandum, D.B.F.P., XVIII, Appendix I, pp. 974-983.

107. Karakhan (Acting Commissar for Foreign Affairs) in a letter to Curzon stated: "[...] Russia, Turkey, Ukraine and Georgia, to whom belongs practically the whole of the Black Sea coast, 
Karakhan on 24th September-replying to a semi-official English statement which had described Great Britain, France and Italy as the most interested countries in the Straits' question- despatched a note to the Governments of Great Britain, France, Italy, Bulgaria, Rumania, Greece and Egypt, protesting against the assumption that Allied interests should be regarded as more important than those of Russia; yet, he pointed out the danger of allowing the present troubles to escalate, declaring that the fate of the Straits would have to be decided by conference of the Black Sea Powers, and expressed the substance of Soviet view:

Any decision taken without Soviet Russia's participation ${ }^{10 x}$ and against her interests would be neither final nor lasting. All it could cause will be new conflicts. The freedom of the Straits which Great Britain has in mind signifies only the desire of a strong naval power to control a route vitally necessary to other States in order thereby to keep them under a constant threat. This threat is directed in the first place against Russia and Turkey ${ }^{10 \%}$.

The threat was clear enough, but in vain; one day before the London Government had consented to the immediate concession of Eastern Thrace to the Turks, consequently the control of the Straits was restored to them.

Ultimately, Great Britain, abandoned by her Allies ${ }^{110}$, militarily weak, embarrassed because of the complicated situation and the conflicting interests arising from it, and facing the possibility of a new war with Turkey'", was

cannot admit the right of any other Government to interfere in the settlement of this question of the Straits and will maintain the point of view above set out, even if the contrary point of view is backed by military or naval superiority". Footnote 4 in D.B.F.P., XVIII, no. 38.

108. The British finally admitted that, because of Russia's vital commercial and strategic interests in this area, no permanent settlement or statute dealing with the Straits, to which Russia would not be a party, was possible to be concluded. F.O. 371/7900, E 10727/27/44, Memorandum by A. Forbes regarding the participation of Russia in the future Peace Conference with Turkey, 27 September 1922.

109. F.O. 371/7895, E 9970/27/44, Karakhan to Curzon, 24 September 1922; See also L. A. Mackfie, "The Chanak Affair (September-October 1922)", Balkan Studies, vol. 20 Thessaloniki (1979), p. 339.

110. Not only France, Italy and Dominions but the Balkan States as well refused to send troops at Chanak for making a common front with Britain, in order to secure the freedom of the Straits and prevent the return of the Turks to Europe. B. C. Busch, op. cit., p. 348; D. Dakin, op. cit., p. 550 .

111. D. Walder, op. cit., p. 311; On the contrary, in Churchill's opinion, there has never been 
compelled to retreat on the question of Eastern Thrace ${ }^{112}$ and the Gallipoli peninsula sacrificing, in this way, "sacred and imperial interest of the British Empire""113.

The statements about freedom "to the populations subjected to the bloody tyranny" ", and the promises of expulsion of the Turks from Europe-since they were an "ulcer" "115 for the European civilizaton- affected nobody any more. The Anglo-French rivalry in the East, which had caused the Graeco-Turkish war ${ }^{116}$, reached an end. The note of 23rd September - which paved the way to the conclusion of Mudania Armistice on 11 October- made it quite obvious that Greece, although exhausted and in urgent need of immediate help, was abandoned after she had been acting in Asia Minor for three years essentially as a mandatory of the Entente Powers ${ }^{117}$; the Greek collapse, however, dragged down with her the British security system as it had been built up after the Treaty of Sevres and caused many doubts about the British Democracy's susceptibility ${ }^{118}$.

any danger to the British forces at Chanak. Kemal advanced against Britain without having no intention, however, to fight with her. What he wanted was to frighten her and to compel her to retreat, since he knew very well that the war-worn, impoverished and demobilized Britain would not stand to fight, while on the other hand, he was aware of the fact that she was the "key" to fulfil the Turkish national aspirations. W. S. Churchill, op. cit., pp. 429, 433.

112. The British conceded Eastern Thrace although knew well that the majority of its population was Greek, so long as in a minute by G. H. Fitzmaurice, on 9 April 1920, was mentioned the official Turkish statistics of 1894 for that region, which gave the following numbers: 304,537 Greeks, 265,359 Turks and 72,758 Bulgars. F.O. 371/5141, E 2830/139/44; M. L. Smith, op. cit., p. 317.

113. D.B.F.P., XVIII, no. 41.

114. Official Statements of War Aims and Peace Proposals, ed. by B. T. Scott, Washington 1921, p. 37.

115. D. Lloyd George, Memoirs of the Peace Conference, vol. II, New Haven 1939, p. 658.

116. A.Y.E., 1922, A/5/VI , П. 468, X. Simopoulos to Foreign Ministry, Constantinople, 25 July 1922; "This is really a battle between England and France for the possession of Anatolia". Arnold Toynbee citing this remark of a Greek soldier, he agrees that the essence of the afore-said remark conveys the true sense of the relations between the Western Powers. A. Toynbee, op. cit., p. 39.

117. Araloff, speaking officially in the name of his Government, in a statement to the newspaper Euyud described the Greeks merely as a tool of the Allied Powers. F.O. 371/7889, E 9444/27/44, S.I.S. to Foreign Office, 12 September 1922; W. S. Churchill, op. cit., p. 384; Professor A. Toynbee expressed the view that Greece acted as a British pawn in Anatolia; the Greeks putting their army between the British and the constantly growing Kemalist movement, gave them the chance to forward their plans and secure their vital interests into the Middle East. A. Toynbee, op. cit., p. 92.

118. W. S. Churchill, ibid.; H. Nicolson, op. cit., pp. 270-271, 388; See also D.B.F.P., XVIII, no. 34 . 
The Allied note of 23 September was undoubtely a great diplomatic success for the Turks; it was they alone, of all the nations defeated in 1918, who were able to transform themselves into victors and force the Allied Powers to negotiate a new peace treaty with them on equal terms, thereby securing the substance of their demands - particularly the recapture of Eastern Thracewithout striking a blow.

If, nevertheless, the only loss for the British Lion was to cease roaring at the crossroads between Europe and Asia, the tragic disappointment of a whole nation, accompanied by a national disaster, pertained exclusively to the Greeks ${ }^{119}$.

119. Venizelos' letter to Curzon, D.B.F.P., XVIII, no. 122; As, characteristically, Professors Christos Rozakis and Petros Stagos write: “[...] The Greek military expansion to Asia Minor had cost Greece dearly and Great Britain almost nothing, for the British not only got the Mosul-which with the collapse of the Greek battle front in Asia Minor and the Turks busy chasing and slaughtering Greeks, the British were unimpeded when they sent parts of their Arab army, in October 1922, into Mesopotamia and occupied Mosul- but also asked Greece, in August 1922, to pay back the loans that London had provided two years previously to help pay the exorbitant costs of the Greek expedition in Asia Minor". Ch. Rozakis - P. Stagos, "The Turkish Straits", in a series on International Straits of the World, vol. 9, Dordrecht 1987, p. 33. 